\title{
Familial osteopetrosis in Agouti paca: report of nine cases
}

\author{
[Osteopetrose familiar em Agouti paca: relato de nove casos]
}

\author{
P.S. Coutinho, N.M. Ocarino, M.B. Ferreira, R. Resende, V.L. Silva, \\ R.M.C. Guedes, R. Serakides* \\ Escola de Veterinária - UFMG \\ Caixa Postal 567 \\ 30123-970 - Belo Horizonte, MG.
}

\begin{abstract}
Nine cases of familial osteopetrosis were studied in Agouti paca rodents maintained in captivity. Animals were distributed in three groups depending on the severity of their skeletal lesions. Based upon clinical, radiological, and microscopic findings, it was concluded that one animal had level I lesions, three animals had level II lesions, and five animals had level III osteopetrosis and osteonecrosis. Throughout the entire axial and appendicular skeleton, there was an increased amount of both trabecular and cortical bone tissue. All analyzed bones showed thickened cortex and reduced medullary canals. Bone trabeculae were thick and confluent. Cortex showed a narrowing of Haversian canals. Numerous cementing lines resulted in typical mosaic patterns. Osteocytes were pycnotic. Osteonecrosis was characterized by the disappearance of osteocytes and bone matrix decomposition.
\end{abstract}

Keywords: Agouti paca, familial disease, osteonecrosis, osteopetrosis, skeleton

\section{RESUMO}

Descreveram-se nove casos de osteopetrose familiar em Agouti paca mantidas em cativeiro. Os animais foram distribuidos em três grupos de acordo com a gravidade das lesões do esqueleto. Com base nos exames clínico, radiológico e microscópico, foi concluido que um animal apresentou lesões de nível I, três animais tiveram lesões de nivel II e cinco animais tiveram osteopetrose de nível III. Por todo o esqueleto axial e apendicular, a quantidade de osso trabecular e osteônico estava aumentada. Todos os ossos analisados mostraram córtex espesso e canais medulares reduzidos. As trabéculas ósseas eram espessas e confluentes. No córtex, verificou-se um estreitamento de canais de Havers. Numerosas linhas de cimentação resultaram em um padrão de mosaico típico. Osteócitos estavam picnóticos e a osteonecrose foi caracterizada pela morte dos osteócitos, com desintegração da matriz óssea.

Palavras chave: Agouti paca, doença familiar, osteopetrose, esqueleto

\section{INTRODUCTION}

Metabolic osteopetrosis and osteonecrosis are generalized diseases. Osteopetrosis is characterized by a systemic increase in the bone mass (Rozin et al., 2005) due to an increase in bone apposition or a decrease in bone resorption. Osteonecrosis is characterized by death of osteocytes and decomposition of bone matrix (Krook et al., 1971). In domestic animals, the main causes of osteopetrosis and osteonecrosis are vitamin $\mathrm{D}$ and corticoid intoxication, fluorosis, and hypercalcitonism (Krook et al., 1971). In humans, the main cause of osteopetrosis is genetic mutation (Senel et al., 2002; Helfrich, 2003).

Reports of osteopetrosis and osteonecrosis in wildlife animals are rarely found in the literature. There are reports of osteopetrosis in deer (Odocoileus virginianus) (Smits and Bubenik,

Recebido em 30 de janeiro de 2007

Aceito em 15 de outubro de 2008

*Autor para correspondência (Corresponding author)

E-mail: serakide@dedalus.lcc.ufmg.br 
1990) and in two marine mammal species, including dugongs (Dugong dugon) and manatees (Trichechus manatus latirostris) (Fawcett, 1942). Osteopenic diseases, including osteoporosis, osteomalacia, fibrous osteodystrophy, and secondary-nutritional hyperparathyroidism are the main osteometabolic diseases that affect wildlife animals maintained in captivity. The main reason for these occurrences is the lack of knowledge about the diet habits of these animals (Fowler, 1993).

Maintenance of those animals in captivity requires knowledge about the biology, physiology, nutrition, ethology, and epidemiology of the animals, in addition to several aspects related to the animal health.

The aim of this study was to describe reports of familial osteonecrosis and osteopetrosis in nine Agouti paca maintained in captivity and fed according to the recommendations of the current literature.

\section{CASE REPORTS}

Nine pacas (Agouti paca) six females and three males, originated from Peti Reservoir, Minas Gerais State, were sent to a veterinary hospital from 1997 to 2005. This reservoir has the purpose of procreating this species in captivity and reintroducing it in the nature.

Clinically, five animals presented intense and painful sensitivity in their locomotor system, mainly in the limbs and spine. Two of these animals presented difficulty to move about and showed paralysis of the pelvic limbs. All of them showed hyporexia and ingested only soft food.

Radiological examination of the most symptomatic animals revealed an increase in radiopacity in the entire axial and appendicular skeleton. In the two animals that showed paralysis, exostoses were found in vertebral body of the last two thoracic vertebrae. Exostoses were projected towards the vertebral canal.

In spite of these animals being treated with corticosteroids, there was no clinical improvement and, therefore, they underwent euthanasia and a post-mortem evaluation was carried out.
Necropsy indicated that cranial and mandibular bones were highly thickened. All long bones showed a thick cortex and a reduced medullary canal (Fig. 1A). Projections of bone tissue occasionally occurred towards the inner portions of the canal (enostosis). Two animals also presented exostoses in the last thoracic vertebrae with spinal canal stenosis (Fig. 1B). These exostoses were projected towards the vertebral canal and led to the compression of the spinal cord and paralysis of pelvic limbs. All long bones had articular cartilages without any apparent changes. Samples of long bones were frozen at $-20^{\circ} \mathrm{C}$ for fluorine dosage in bone ashes.

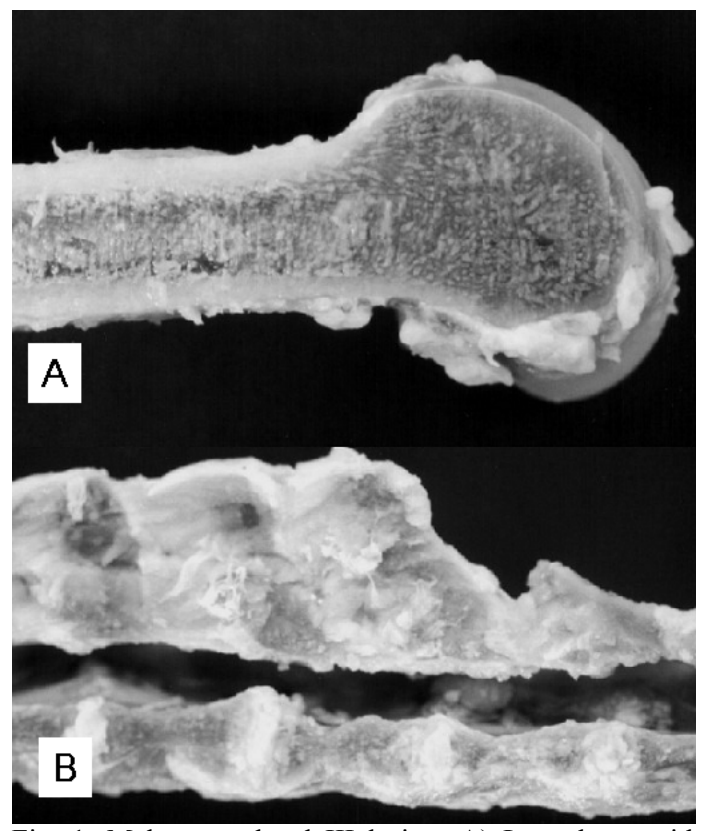

Fig. 1. Male paca, level III lesion. A) Long bone with thickened cortical and medullary cavity occupied by bone. B) Exostoses in the last thoracic vertebrae with spinal canal stenosis.

Other post-mortem radiological examinations of long bones, skull, and vertebrae were performed, revealing the same characteristics clinically observed (Fig. 2A, B, C). In the other four less symptomatic animals, the increase in radiodensity was predominantly found in frontal and nasal portions of the skull and in long bone epiphyses (Fig. 3A, B). In these animals there was a better distinction between the medullary canal and the cortex when compared to the most symptomatic animals. Among these four animals, two exhibited an increase in vertebral radiopacity, whereas the other two were normal (Fig. 3C). 


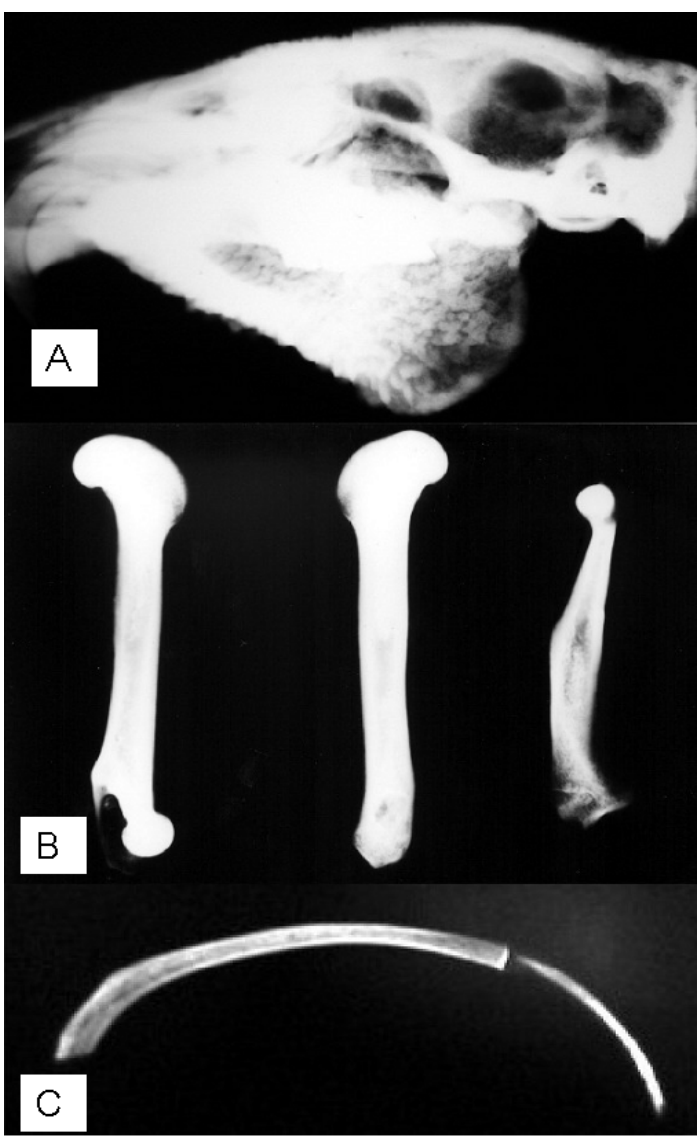

Fig. 2. Male paca, level III lesion. A) Skull presenting increase of diffused radiopacity. B) Long bones showing increased radiopacity and little distinction between the cortex and the medullary canal. C) Costochondral cartilage mineralization.

Fragments from all the skeleton bones, brain, heart, lungs, kidneys, and liver from every animal were fixed in $10 \%$ neutral formalin. Bones were demineralized under water pump vacuum in $10 \%$ formic acid buffered to $\mathrm{pH} 4.5$ with sodium citrate, routinely processed, and the sections were embedded in paraffin and stained with hematoxylin and eosin.

Microscopic analysis showed that all animals, regardless of being more or less symptomatic, presented microscopic alterations that could be characterized as osteopetrosis and osteonecrosis.

Histologically, there was an increase in the amount of trabecular and cortical bone tissue in the entire appendicular and axial skeleton. All the analyzed bones showed thickened cortical and reduced medullary canal. Epiphyseal and metaphyseal trabeculae were thick, confluent, and concentrically arranged, with osteonic configurations (Fig. 4A).

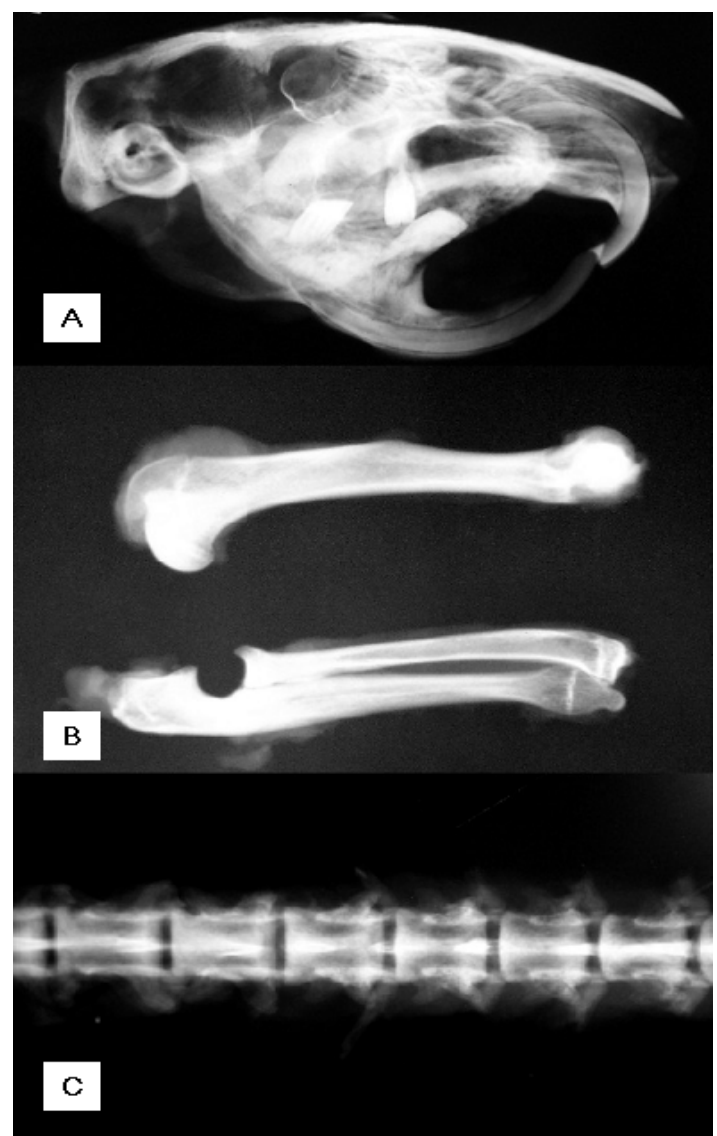

Fig. 3. Female paca. A) Level II lesion. Skull presenting increased radiopacity in frontal and nasal regions. B) Level II lesion. Long bones showing increased radiopacity only in epyphysis. C) Level I lesion. Thoracic vertebrae with normal radiopacity.

Sometimes, it was impossible to distinguish between areas of trabecular and compact bone tissue. Transverse sections of medullary cavity at the mid-diaphysis were occupied by bone trabeculae. Numerous cementing lines resulted in mosaic patterns (Fig. 4B) indicative of retarded osteocytic osteolysis. In the trabecular and cortical bone tissue, there was a moderate amount of chondroid core surrounded by inactive osteocytes, indicative of retarded osteocytic chondrolysis. Osteocytes were pycnotic, located inside widened lacunae. Osteonecrosis was characterized by the disappearance of osteocytes (Fig. 4C) and decomposition of bone matrix (Fig. 4D). There was little osteoclasia and osteoblasts were normal. The vertebral exostoses were constituted by matured bone tissue. Myelin degeneration was observed in the spinal cords of the two animals with vertebral exostoses and compression of the spinal cord. Articular cartilage and epiphyseal plate (when present) were normal in all animals. 
Sorting through the nine cases analyzed, the levels of skeletal lesions were classified as follows: level I lesions: discrete symptoms, as well as macro and microscopic changes in addition to multifocal radiological changes; level II lesions: discrete symptoms and macroscopic changes, multifocal radiological changes and moderate to intense microscopic changes; and level III lesions: severe symptoms, as well as macro and microscopic changes, radiological changes throughout the entire skeleton.

Both male and females were equally affected. Based upon clinical, radiological, and microscopic findings, it was concluded that one animal had level I lesions, three animals had level II lesions, and five animals had level III osteopetrosis and osteonecrosis (Table 1).

Samples from the brain, heart, lungs, kidneys, and liver were collected at necropsy of all animals, and did not show any macro or microscopic changes. The fluorine measurement in the bones was 100ppm.

Daily amounts of commercial concentrate, fruits, vegetables, and corn ingested by pacas were calculated (Table 2). Based on the total diet daily consumed, percentages of calcium, phosphorus, and vitamin D were calculated (Table 3), and compared to the values recommended in the literature.

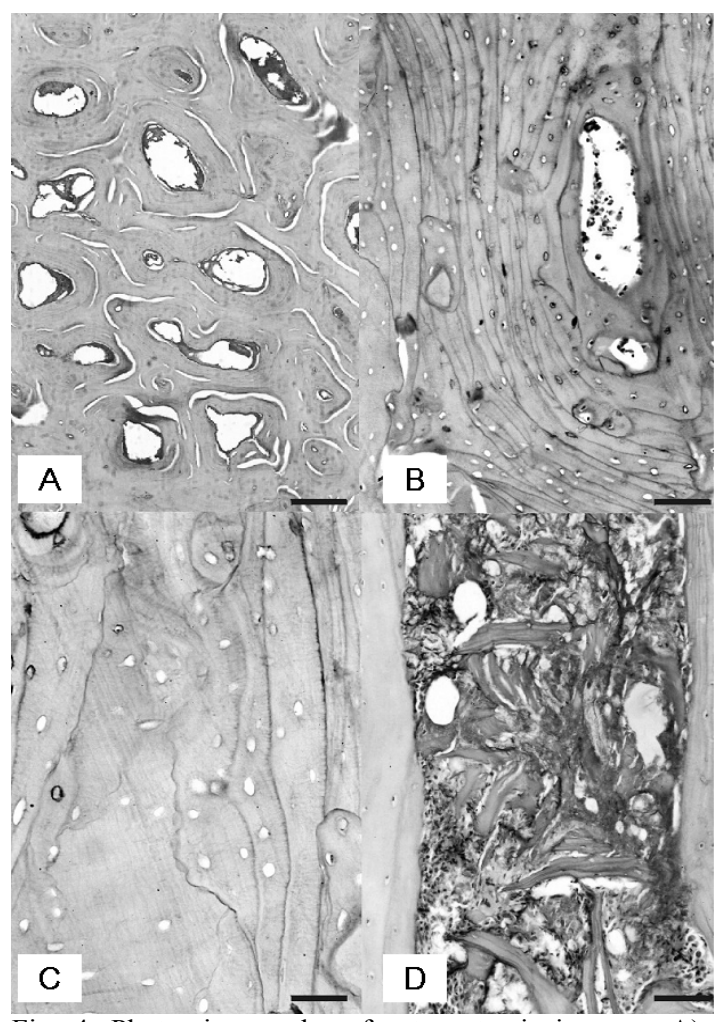

Fig. 4. Photomicrography of osteopetrosis in paca. A) Long bone. Thick, confluent and concentrically arranged trabeculae, with osteonic configurations (HE, bar: $45 \mu \mathrm{m}$. B) Vertebra. Pycnotic osteocytes, lodged in widened lacunae, and numerous cementing lines resulting in typical mosaic patterns. (HE, bar: $13 \mu \mathrm{m}$. C) Vertebra. Site of osteonecrosis characterized by disappearance of osteocytes. (HE, bar: $7 \mu \mathrm{m}$. D) Vertebra. Site of osteonecrosis characterized by decomposition of bone matrix. (HE, bar: $13 \mu \mathrm{m}$ ).

Table 1. Summary of clinical, radiological, macro and microscopic findings and levels of lesion present in each animal

\begin{tabular}{llcccccc}
\hline Animal & Gender & $\begin{array}{c}\text { Age } \\
\text { (years) }\end{array}$ & Symptoms & $\begin{array}{c}\text { Macroscopic } \\
\text { findings }\end{array}$ & $\begin{array}{c}\text { Radiologic } \\
\text { findings }\end{array}$ & $\begin{array}{c}\text { Microscopic } \\
\text { findings }\end{array}$ & $\begin{array}{c}\text { Level of } \\
\text { lesions }\end{array}$ \\
\hline 1 & female & $8 \#$ & present & present & difuse & intense & III \\
2 & male & $9 \#$ & present & present & difuse & intense & III \\
3 & female & 10 & present & present & difuse & intense & III \\
4 & male & 9 & present & present & difuse & intense & III \\
5 & female & 6 & present & present & difuse & intense & III \\
6 & male & 9 & absent & absent & multifocal & moderate & II \\
7 & female & 6 & absent & absent & multifocal & moderate & II \\
8 & female & 8 & absent & absent & multifocal & discrete & I \\
9 & female & 6 & absent & absent & multifocal & intense & II \\
\hline
\end{tabular}

\# Years of captivity (animal captured from the nature)

Level I lesions: discrete symptoms, as well as macro and microscopic changes, multifocal radiological changes; level II lesions: discrete symptoms and macroscopic changes, multifocal radiological changes and moderate to intense microscopic changes; and level III lesions: severe symptoms, as well as macro and microscopic changes, radiological changes throughout the entire skeleton. 
Table 2. Daily consumpion of commercial concentrate, fruits, and vegetables (mean and standard deviation), in grams, per animal and total consumption of food per animal/day

\begin{tabular}{lcccccc}
\hline Food & 2000 & 2001 & 2002 & 2003 & 2004 & 2005 \\
\hline Ration $(\mathrm{g})$ & $133.63 \pm 31.6$ & $70.05 \pm 10.9$ & $74.63 \pm 14.4$ & $61.37 \pm 10.8$ & $54.57 \pm 6.29$ & $62.53 \pm 4.85$ \\
Fruits $(\mathrm{g})$ & $234.75 \pm 13.7$ & $165.2 \pm 25.4$ & $222.88 \pm 35.9$ & $359.79 \pm 54.3$ & $345.22 \pm 52.9$ & $257.33 \pm 10.68$ \\
Vegetables $(\mathrm{g})$ & $214.90 \pm 12.1$ & $186.29 \pm 8.4$ & $215.38 \pm 53.8$ & $484.56 \pm 61.4$ & $513.30 \pm 62.7$ & $361.33 \pm 14.5$ \\
\hline Total/animal/day & $583.28 \pm 19.1$ & $421.54 \pm 14.9$ & $512.9 \pm 34.7$ & $905.72 \pm 42.2$ & $913.1 \pm 40.6$ & $681.9 \pm 10.01$ \\
\hline
\end{tabular}

Table 3. Percentages of calcium and phosphorus (mean and standard deviation) daily ingested per animal and amount of vitamin $\mathrm{D}$ ingested per animal/day

\begin{tabular}{ccccccc}
\hline & 2000 & 2001 & 2002 & 2003 & 2004 & 2005 \\
\hline $\begin{array}{c}\text { Calcium } \\
(\%)\end{array}$ & $0.58 \pm 0,000808$ & $0.42 \pm 0.000576$ & $0.37 \pm 0.00054$ & $0.18 \pm 0.000496$ & $0.16 \pm 0.00022$ & $0.24 \pm 0.00022$ \\
$\begin{array}{c}\text { Phosphorus } \\
(\%)\end{array}$ & $0.14 \pm 0.00015$ & $0.11 \pm 0.00011$ & $0.10 \pm 0.0009$ & $0.07 \pm 0.0000961$ & $0.07 \pm 0.00061$ & $0.08 \pm 0.00022$ \\
$\begin{array}{l}\text { Vit. D } \\
\text { UI/day }\end{array}$ & $1336.4 \pm 316.4$ & $700.5 \pm 109.5$ & $497.5 \pm 144.6$ & $306.8849 \pm 252.1$ & $272.8 \pm 62.9$ & $260.5 \pm 48.5$ \\
\hline
\end{tabular}

The degree of kinship among affected animals is shown by a genealogical tree (Fig. 5). The animals 1 and 2 were captured in the same area and both presented intense osteopetrosis. This couple gave origin the great part of the other animals. Although there were not parents crossing with sonny, the consanguinity happened due to the crossing among siblings. All the affected animals belonged to the same family.

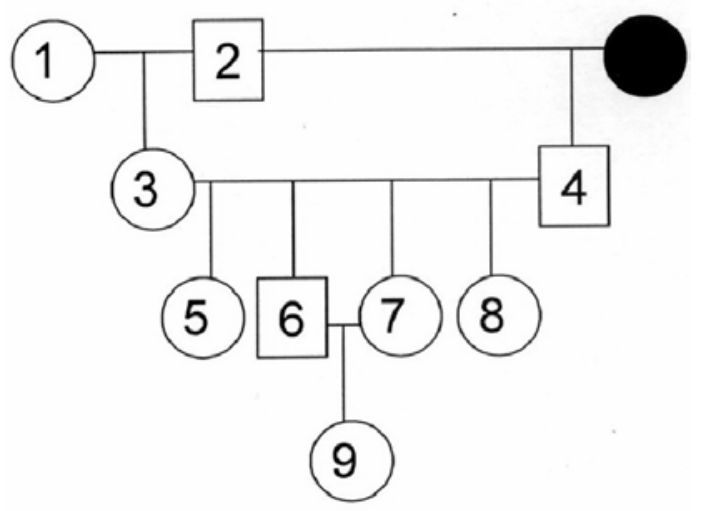

$\bigcirc$ Female

Female captured and not examined

Male

Fig. 5. Genealogical tree of examined animals demonstrated by numbers.

\section{DISCUSSION}

Macro, microscopic, and radiological findings can be classically linked to osteopetrosis and osteonecrosis.
The clinical evidences observed in five animals, including the difficulty to move about and to chew are related to the compression of both pelvic limbs nerves and facial nerves, in concurrence with Steward (2003). The encountering of discrete symptoms in four animals can be related to the fact that these animals had less severe radiological and histological changes.

Osteopetrosis is an osteometabolic disease characterized by an increase in the amount of bone, which can be a result of larger bone apposition or smaller bone resorption. In the reported case, it is evident by the microscopic findings that osteopetrosis resulted from a smaller bone resorption.

Osteonecrosis was another change observed, which was characterized by the disappearance of osteocytes and decomposition of bone matrix (Glade and Krook, 1982). In this case, osteonecrosis might have been a follow-up occurrence to osteopetrosis, which means that the increase in the amount of bone tissue compromises the nutrition of osteocytes and, consequently, leads to the death of these cells (Kramers et al., 1988). When osteonecrosis is followed only by the death of osteocytes with no decomposition of bone matrix, there is no change to the radiological image of the bone. For this reason, some animals that showed increase of radiopacity also presented osteonecrosis, microscopically. 
Food control for pacas involved the supply of rabbit ration, fruits (bananas, avocados, pears, and mangoes) and vegetables (sweet potatoes, corns, and pumpkins). The amount of food offered to the animals along with the percentage of minerals and vitamins on their diet were in accordance with the recommendations of the FAO (Dieta..., 2005). But, the percentage of calcium and phosphorus recommended is $0.43 \%$ and $0.20 \%$, respectively, higher than the concentration found in the total diet of pacas. Hence, hypercalcitoninism resulting from excessive ingestion of calcium was disregarded from the etiology of osteopetrosis in this particular case. The use of rabbit ration in these cases is also recommended in the literature. Sedgwick and Fowler (1972) pointed out that the commercial rations used for lab rodents, rabbits, some herbivores, and carnivores are also recommended for wildlife animals maintained in captivity.

Calcitonin in excess also acts in growth cartilages and it delays the differentiation of their cells resulting in osteocondrosis (Krook, 1983). If the cause of osteopetrosis in these pacas was hypercalcitoninism, alterations would be expected in endocondral growth (osteocondrosis) in animals that were born and that grew in the captivity. However, no osteocondrosis sign was observed in the animals of this study.

Vitamin D intoxication was also eliminated as a possible cause of this disease, as the vitamin D form present in the ration was 25 hydroxycholecalciferol (the inactive form of vitamin D). Moreover, ingestion of vitamin D by animals was lower than the amount recommended by FAO. Furthermore, there were no soft tissue calcifications, which are commonly found in cases of intoxication by vitamin D (Mello et al., 1999). At histology, in bones of animals intoxicated by Vitamin D, there were osteoblastic hypotrophy and changes in bone growth (Krook et al., 1975). Those changes were not present in the bones of any animal.

For this reason, bone fluorine concentrations were investigated and the results proved that they were even below the acceptable limits established by the literature. On that account, in this case, osteopetrosis was not a result of fluorosis.
The treatment with corticosteroids using low concentrations for a short period of time was not considered the cause of osteopetrosis, since this treatment was only performed in the two animals that showed paralysis. According to the literature, osteopetrosis usually occurs due to high doses $(5 \mathrm{mg} / 100 \mathrm{~kg}$ PV) of corticosteroids administered for at least three months (Glade and Krook, 1982).

Microscopic examination of various tissue samples collected from the organs at necropsy did not show any change, thus disregarding the relationship between osteopetrosis/osteonecrosis and an infectious process.

In the literature, several types of hereditary osteopetrosis in human can be found. Filho et al. (2005) mentioned a kind of osteopetrosis that can affect children and adults with or without clinical symptoms. This is a hereditary recessive autosomic disease with diffuse osteoclerosis. Congenital osteopetrosis has been described in several domestic animal species (Riser and Fankhauser, 1970; Greene et al., 1974; Nation and Klavano, 1986). However, no cases of familial osteopetrosis were described. In the present study, genealogical tree shows that animals affected with osteopetrosis and osteonecrosis presented close degree of kinship, thus, being considered from the same family. Therefore, family involvement associated to discarding nutritional causes suggests that the cause of osteopetrosis and osteonecrosis was genetic.

It is concluded that osteopetrosis and osteonecrosis observed in nine pacas from the Peti reservoir were due to reduced bone resorption. As the diet was according to the recommendations of FAO, the etiology was not dietary, disregarding the possibility of hypercalcitonism, vitamin D intoxication, as well as, fluorosis and corticoid intoxication. Family involvement of osteopetrosis and osteonecrosis suggests genetic etiology.

\section{ACKNOWLEDGEMENTS}

The authors would like to thank the Peti reservoir officer. 


\section{REFERENCES}

DIETA. In: La domesticacion y cria de la paca (Agouti paca) - Guia FAO Conservación. Cap.10, p.47-53, 1995. Disponível em: $<$ http://www.fao.org/documents/show cdr.asp?u rl file=/DOCREP/006/V4940S/V4940S00.HTM

>. Acessado em: 20 dez. 2005.

FAWCETT, D.W. The amedullary bones of the Florida manatee (Trichechus latirostris). Am. J. Anat., v.71, p.271-309, 1942.

FILHO, A.M.; CASTRO DOMINGOS, A.; FREITAS, D.Q. et al. Osteopetrosis - a review and report of two cases. Oral Dis., v.11, p.46-49, 2005.

FOWLER, M.E. Zoo and wild animal medicine: current therapy. Philadelphia: W.B. Saunders, 1993. $617 \mathrm{p}$

GLADE, M.J.; KROOK, L. Glucocorticoidinduced inhibition of osteolysis and the development of osteopetrosis, osteonecrosis and osteoporosis. Cornell Vet., v.72, p.76-91, 1982.

GREENE, H.J.; LEIPOLD, H.W.; HIBBS, C.M. et al. Congenital osteopetrosis in Angus calves. J. Am. Vet. Med. Assoc., v.164, p.389-395, 1974.

HELFRICH, M.H. Osteoclast diseases. Microsc. Res. Tech., v.61, p.514-532, 2003.

KRAMERS, P.; FLUCKIGER, M.A.; RAHN, B.A. et al. Osteopetrosis in cats. J. Small Anim. Pract., v.29, p.153-164, 1988.

KROOK, L. Metabolic disease of bone and bones. New York: Cornell University, 1983. 54p.

KROOK, L.; LUTWAK, L.; McENTEE, K. et al. Nutritional hypercalcitoninism in bulls. Cornell Vet., v.61, p.625-639, 1971.
KROOK, L.; WASSERMAN, R.H.; MCENTEE, $\mathrm{K}$. et al. Cestrum diurnum poisong in Florida cattle. Cornell Vet., v.65, p.557-575, 1975.

MELLO, J.R.B.; LANGELOH, A.; HABERMEHL, $G$. et al. Influência da administração de extratos de duas plantas calcinogênicas sobre a fertilidade de ratos. Arq. Bras. Med. Vet. Zootec., v.51, p.453-462, 1999.

NATION, P.N.; KLAVANO, G.G. Osteopetrosis in two foals. Can. Vet. J., v.27, p.74-77, 1986.

RISER, W.H.; FANKHAUSER, R. Osteopetrosis in a dog. J. Am. Vet. Radiol. Soc., v.11, p.29-34, 1970.

ROZIN, A.; BAR-SHALOM, R.; ISHSHALOM. Paget's disease of bone or osteopetrosis? Clin. Rheumatol., v.19, p.1-4, 2005.

SEDGWICK, C.J.; FOWLER, M.E. Methods of feeding mammals. In: ANNUAL MEETING OF THE AMERICAN ASSOCIATION OF ZOO VETERINARIANS, $1972 . \quad$ Atlanta Proceedings... Atlanta, 1972. p.177-221.

SENEL, K.; UGUR, M.; ERDAL., A. et al. Type II autosomal dominant osteopetrosis. Rheumatol. Int., v.22, p.116-118, 2002.

SMITS, B.; BUBENIK, G.A. Congenital osteopetrosis in White-tailed deer (Odocoileus virginianus). J. Wildl. Dis., v.26, p.567-571, 1990.

STEWARD, C.G. Neurological aspects of osteopetrosis. Neuropathol. Appl. Neurobiol., v.29, p.87-97, 2003. 